\title{
MI 2,1-9 e 2,17-3,5: crise do Sacerdócio e Escatologia no séc. V a.C.
}

Orientadora: Maria de Lourdes Corrêa Lima

Doutorando: Fábio da Silveira Siqueira

Área de Concentração: Teologia Bíblica

Linha de Pesquisa: Análise e Interpretação de Textos do Antigo e Novo Testamento

Projeto de Pesquisa: O sistema verbal hebraico na literatura profética bíblica

A presente pesquisa tem como objetivo principal estudar o modo como se relacionam, no profeta Malaquias, a crise do sacerdócio, descrita de modo particular em 2,1-9, e a perspectiva escatológica apresentada em 2,17-3,5. A pesquisa considera que, embora em 2,1-9 prevaleça o discurso de juízo sobre os sacerdotes faltosos, no v. 4 é delineada uma perspectiva salvífica. Tal perspectiva é desenvolvida em 2,17-3,5, onde o tema da purificação do sacerdócio e do restabelecimento do culto domina a maior parte do texto $(3,2-4)$. Para o estudo das unidades textuais seguiu-se o Método Histórico Crítico nas suas etapas essenciais, conjugando-o, de modo particular no comentário aos textos, com a análise sincrônica, considerando-se cada uma das perícopes na sua forma final e canônica. Com relação a 2,17-3,5 procurou-se identificar os elementos que permitem caracterizar este texto como escatológico e delinear suas perspectivas principais. $\mathrm{O}$ estudo conjunto das perícopes demonstrou que, em Malaquias, o juízo previsto em 2,1-9 é revertido a partir da perspectiva escatológica apresentada em 2,17-3,5. Uma vez que os sacerdotes são os ministros do culto e este é a manifestação da dimensão propriamente religiosa da relação de Deus com seu povo, YHWH mesmo agirá, em primeiro lugar por meio de seu mensageiro, purificando os sacerdotes e restabelecendo o culto na sua integridade e, depois, atuando como "testemunha" contra os que não o temem.

Palavras-chave: Livro de Malaquias. Culto. Sacerdócio. 